Relations industrielles

Industrial Relations

\title{
Theresa S. Malliel, The Diary of a Shirtwaist Striker
}

\section{Isik Urla Zeytinoglu}

Volume 46, numéro 4, 1991

URI : https://id.erudit.org/iderudit/050725ar

DOI : https://doi.org/10.7202/050725ar

Aller au sommaire du numéro

Éditeur(s)

Département des relations industrielles de l'Université Laval

ISSN

0034-379X (imprimé)

1703-8138 (numérique)

Découvrir la revue

Citer ce compte rendu

Zeytinoglu, I. U. (1991). Compte rendu de [Theresa S. Malkiel, The Diary of a Shirtwaist Striker]. Relations industrielles / Industrial Relations, 46(4), 867-868. https://doi.org/10.7202/050725ar

Tous droits réservés @ C Département des relations industrielles de l'Université Laval, 1991
Ce document est protégé par la loi sur le droit d'auteur. L'utilisation des services d'Érudit (y compris la reproduction) est assujettie à sa politique d'utilisation que vous pouvez consulter en ligne.

https://apropos.erudit.org/fr/usagers/politique-dutilisation/ 
The Diary of a Shirtwaist Striker, by Theresa S. Malkiel, with an introductory essay by Françoise Basch, Ithaca, N.Y., ILR Press, School of Industrial and Labor Relations, Cornell University, 1990, 212 p., ISBN 0-87546-168-9

This is the long-forgotten but recently-revived story of a strike by 20,000 to 30,000 women in the shirtwaist industry in New York City in 1909-1910. It is the story of women organizing into unions, gaining consciousness and joining into a 'sisterhood' against the powerful front of their employers, the legal systems, the police, other male-dominated unions, and even their families.

The book is divided into two sections. The first section is the introductory essay by Françoise Basch. She analyzes the fictional story of the strike in the context of class, ethnicity, and gender. This section is divided into four subsections. The first subsection discusses the strikers' lives at work and at home, with particular reference to Jewish immigrants. It describes the dirty, crowded and inhumane living conditions of Eastern European Jewish as well as Italian, German, Russian and Rumanian immigrants in New York's Lower East Side in early 1900s. The book shows that the working conditions in their workshops were not much different from their living conditions either. This subsection also presents the blend of religious traditions and socialism among Jewish immigrants in the early 1900s, the individualistic behaviour of Jewish workers, and the difficulty in organizing them. By focusing on women in the work place, this subsection also gives examples of the exploitation of women based on class, gender, and ethnicity, as well as instances of racial prejudice and sexual harassment.

In addition, the first subsection gives introductory information on the establishment of the International Ladies Garment Workers Union in 1906, by mostly Jewish workers. It presents the difficulties in organizing women, their involvement and leadership in their unions. Interestingly, this section also shows the differences in attitudes towards unionization among European-Jewish, Italian, American-born white and black women.

The second subsection examines the supporters of the strike and the sequence of events. While "the sequence of events" section is more or less a repetition of The Diary section, the analysis of the supporters of the strikers is worthwhile to read. This section shows how the National Women's Trade Union League (NWTUL), the suffragists, and the Socialist Party of America, each with different political interests, goals and background, approached the strike of the 'girls'. Here the reference to the NWTUL is particularly interesting. It explains how a variety of women - of middle-class origin, blue-collar workers, and daughters of wealthy families - worked together to fight against the oppression of women/workers/immigrants by believing in solidarity.

The third subsection is a short biography of Theresa Serber Malkiel. This subsection might be particularly important and interesting for labour historians, since Basch argues that there is a scarcity of biographical information on Malkiel and her accomplishments. In the last subsection Basch analyzes Malkiel's Diary as an historical account, both fiction and socialist propaganda. She concludes that "For all its old-fashioned overtones and cliches, Theresa Malkiel's story conveys a strong message that class and gender emancipation are inseparable".

The second section of the book is a reproduction of the original edition of the story as published in 1910. It is written in the form of a fictional diary giving the day-to-day account of the developments during the strike. The first-person narrative enables Malkiel to present not only the developments during the strike but also her ideas and opinions as well. Although I found this section to be very interesting, at certain points it seemed to be a socialist propaganda booklet, giving a utopian picture of the future in a socialist America. In addition, I thought 
Malkiel overly praised Jewish 'girls' and gave little credit to other striking women. Despite these shortcomings, the Diary is still an interesting piece on female working-class life, culture and society, as well as socialist politics in the early twentieth century.

Although it has been written for at least 80 years, in reading the story I found many resemblances to present day women and their concerns, particularly to new immigrants in Canada. The poor working and living conditions of women, the language and cultural barriers of immigrant women in their new country, the exploitation of women in the hands of employers who are often from the same country of origin or ethnic background, the doubleburden of women at paid 'outside' work and the unpaid 'housework' were all too familiar to the 1990s Canada. Overall, both Malkiel's fiction and Basch's essay show that the concerns of women workers have not changed much throughout the years.

Assuming most readers have not heard of the 1909-1910 shirtwaist workers' strike, I would recommend them to read the fiction section first, and then read Basch's analysis. This will enable the readers to learn about the strike and to be able to evaluate the fiction for themselves, prior to reading Basch's thoughtful and thorough analysis. I strongly recommend the book to those interested in the history of labour unions, women workers and socialism in North America, as well as to those interested in the origins of feminism in the U.S.A.

Isik Urla ZeYTinogLU

McMaster University

Australian Unions: An Industrial Relations Perspective, edited by Bill Ford and David Plowman, Australia, Macmillan, 1989, viii +323 p., ISBN 0-333-50208-6 and ISBN 0-333-50206-X (pbk)

In the 1980s Australian trade unions had to confront a rapidly changing economic, social, and industrial environment. The decline in the country's manufacturing base combined with a fall in membership numbers and pressures to shift bargaining towards the enterprise level were some of the factors which forced trade unions to revise their aims, strategies and structures. Australian Unions is therefore a timely addition to the available literature on trade unions, although it should be noted that this publication is the second edition of a book first published in 1983.

The editor's major objectives in compiling the book and selecting topics and papers for inclusion were to provide a multidimensional industrial relations perspective to the study of trade unions and to provide an understanding of the complexities of union structures, processes and behaviour. To achieve these objectives the editors structured the book into four parts: the historical and theoretical context of Australian trade unions; organisation and practice; issues and policy; and future context and perspectives. This structure is similar to that of the first edition although several chapters have been discarded to allow for the inclusion of chapters on union theory, the formation of the present day Australian Council of Trade Unions and issues such as technological change and superannuation. Of the chapters retained some have been updated such as the chapters on workplace unionism (an historical development), and unions and immigrants.

The book, therefore, provides a number of perspectives on trade union organisation and structure in Australia and examines in detail some of the key issues addressed by unions during 